\title{
The Effect of Whatsapp in A Flipped Classroom on Students' Writing Achievement at MTsN 1 Konawe
}

\author{
Tarisman
}

\author{
Hilaluddin Hanafi
}

\begin{abstract}
This study aims at finding out the significant effect of using WhatsApp as a media in a flipped classroom on students' writing achievement. This study applied the preexperimental design. The population was the $2017 / 2018$ second grade students of MTsN 1 Konawe which consists of 240 students. The samples were 30 students of Class VIII-2. The experimental class was taught by using WhatsApp Group chat as a flipped classroom media. The tests consisted of pre-test and post- test. The instrument used in this study was a writing test. The data were analyzed by using paired sample t-test. The hyphotesis of this research stated if there was a significant effect of using WhatsApp on students' writing achievement at MTsN 1 Konawe (H1). The result of paired sample ttest shown that the asymp sig. is 0.000 . It means that the asymp sig. was lower than 0.05 $(0.000<0.05)$. Therefore, the $\mathrm{H}_{1}$ is accepted. It can be concluded that WhatsApp has significant effect on students' writing achievement at the second grade students of MTsN 1 Konawe..
\end{abstract}

Key Word: WhatsApp, Flipped Classroom, Writing Achievement

\section{INTRODUCTION}

Social media is a phenomenon that has been prevalent among today's teenagers. Since smartphone is ubiquotus accross the country and globally, the use of smartphone to support daily activities has been prevalent in all level of ages. Excessive use of time in accessing social networking sites may disrupt student learning motivation. In addition, the use of social media can also change the lifestyle, behavior, communication, and ability of a person in socializing with the environment. Regardless of the negative impact, social media networks also have positive benefits for learners. Social media have a positive impact if the use is not excessive. Social media can provide the required information quickly; add insights by searching tasks through existing educational apps, adding friends, completing tasks by creating special groups to discuss together. Among the wide range of advanced mobile applications, WhatsApp Messenger Apps is one of the tools for communication that is used by all levels of society today. Students are also part of modern society that relies on social media all the time to communicate and find information instantly. Given that the majority numbers of students are in junior high school level, it can be assumed that most of the junior high school students are familiar or even accustomed to using social media in their daily lives. The tendency of students to use mobile phone, especially social media is a gap that can be used for educators to attract students' interest in the language learning process. There are several popular social media platforms used by today's students. Examples of such social media are Facebook, BBM, Instagram, Snapchat and the most contemporary is WhatsApp.

In the past few years, WhatsApp has been the most popular social media platform among Smartphone users all over the world. As teenagers, junior high school students are familiarized to this most popular social media platform. Most teenagers have used WhatsApp to interact 
and communicate with friends and acquaintances. They have more knowledge and experience to all features of WhatsApp rather than adults. The regular use of WhatsApp in teenagers' daily life could be a potential opportunity for teachers and educators to engage them in the learning process though the insertion of WhatsApp as learning media that contributes to their involvement learning, as well as make them enjoy and feel comfort to learn with something that they fond of these days.

In contrast to the constructivist approaches of teaching and learning, the traditional language teaching is almost teacher-centered. The problem of traditional teaching makes teacher always be a producer. For some students, the lessons delivered in the classroom quite easier to be understood or comprehend. In the other hand, other students might have difficulties in perceiving the content of the lessons rapidly. Current trends in teaching and learning inquire about developing student-centered learning; in which students take responsibilities of their learning in environments that encourage participation, critical thinking, problem solving, variety of activities, group work and meaningful interactions instead of rote memorization which results in passive students who are incapable of growth and development. The utilization of WhatsApp in second/foreign language learning may lead to construct studentcentered learning through developing their connectivity, collaboration and engagement learning.

\section{Research Questions}

1. Is there any significant effect on students' writing achievement through the utilization of WhatsApp group chat as learning tool?

2. How motivated are the students' in writing English text by using WhatsApp group chat?

3. What is students' perception on the use of WhatsApp in English learning especially writing?

\section{Social Constructivist Theory}

\section{LITERATURE REVIEW}

Social Development Theory argues that social interaction precedes development; consciousness and cognition are the end product of socialization and social behavior (Vygotsky, 1980). Vygotsky focused on the connections between people and the sociocultural context in which they act and interact in shared experiences. According to Vygotsky, humans use tools that develop from a culture, such as speech and writing, to mediate their social environments. Initially children develop these tools to serve solely as social functions, ways to communicate needs. Vygotsky believed that the internalization of these tools led to higher thinking skills.

Al Hamdani (2013) asserts that constructivism, in general, maintains that knowledge is constructed by the individual from within rather than being transmitted to the learner from another outside source. Therefore, learning is seen as a process of actively constructing knowledge by integrating experiences into the learners' prior knowledge; the learner plays an active role in building his/her knowledge. Vygotsky (1980) as cited in Jarvis (2015), the founder of social constructivism, emphasizes the importance of the interaction with the others such as peer, teachers and parents to build knowledge. He also emphasizes the need for tools such as language and computer to mediate knowledge construction.

The proposed constructivist-mobile learning environment is characterized by new roles of teacher and learner, specially designed learning activities and use of mobile as a tool. Switzer and Csapo (2005) argue that mobile devices allow learners' opportunities for collaboration in 
the creation of products and for sharing them among their peers. Patten, Sánchez, and Tangney (2006) assert that the advantages of mobile learning can be gained, through collaborative, contextual, constructionist and constructivist learning environments.

\section{Technology Enhanced Language Learning}

Technology-enhanced language learning deals with the impact of technology on teaching and learning a second language also called the L2. Technology-enhanced language learning refers to the use of the computer as a technological innovation to display multimedia as a means of complementing a teaching method for language teacher. What's important to note is that TELL is not a teaching method but rather an approach that can be used alongside a teaching method to help teaching.

TELL is very supportive of Computer Mediated Communication (CMC). CMC has been researched and supported as being very useful for helping students speak and write in a foreign language which is important to teaching process using TELL. "The process can be described as effectively bridging the gap between written and oral expression for the linguistically limited student whose oral skills are not adequate to allow for full expression of ideas in the target language.

\section{Computer Assisted Language Learning}

Computer Assisted Language Learning (CALL) is an approach in language learning became popular in 1950s, 1960s, and 1970s eras. Behavioristics model of learning-language drills became a frame of the CALL usage in this period, then communicative CALL appeared in the late 1970s and in the beginning of 1980s (Warschauer \& Healey, 1998). They also state that integrative CALL appeared in 1990s whereas the integration of various language skills in teaching and learning by means of technology. Warschauer and Healey (1998) point out that the multimedia networked computer with a range of informational, communicative, and publishing tools now potentially at the fingertips of every student-provides not only the possibilities for much more integrated uses of technology, but also the imperative for such use, as learning to read, write, and communicate via computer has become an essential feature of modern life in the developed world. It could be interpreted that in this period CALL has been able to be used in various language learning skills.

In the early beginning of twenty-first century, CALL has been gradually replaced by the use of smaller and portable devices as laptop usage sooner replaced by mobile device (Beatty, 2013). This is the early beginning of today's popular technology use in language learning called MALL (Mobile Assisted Language Learning).

In contrast, Hubbard (2009) argues that the shift from CALL to MALL is not entirely acceptable. He claims that MALL is merely an extension of CALL.in addition, Hubbard (2009) states that mobile device is part of secondary components of computer as mobile device still need the main function of computer.

\section{Mobile Assisted Language Learning}

In general, MALL means learning with the aid of handheld technologies like mobile phones, PDAs, iPods, iPads and other similar devices which could have an impact on language learning (Valarmathi, 2011). Laptops are not suitable to use in a MALL context based on Viberg and Grönlund (2012) as only "lightweight" devices are being used. Even though mobile learning and MALL is commonly known as the same thing, Valarmathi (2011) noted that MALL is actually a subset of both Mobile learning (m-learning) and Computer Assisted Language Learning (CALL). 
Mobile learning has several features that are useful in our digital society which benefits the students in many ways. Here are some of the features listed below:

\section{a. Mobility}

The size and weight of mobile technology differs from one another yet it can be moved and carried easily. The devices' portability enable learners to use it anytime and anywhere; even outside of classrooms and lecture halls like in cafes, hobby stores, cars and more (Sharples, Taylor, \& Vavoula, 2005).

\section{b. Ubiquity}

Mobile devices can be seen everywhere and it seems that everyone is using it, even in third world countries like Iraq and Iran. This is supported by Samsiah et al. (2013) who said that mobile devices are considered as an international phenomenon where even kids as young as 2 years old already know how to use it.

\section{c. Wireless networking}

Smart phones now combine the functions of phone, camera and multimedia wireless computer. This is one of the most significant features as it allows learners to have limitless internet connection without the help of any other device or wiring. This convergence allows new conceptions of lifelong learning (Sharples et al., 2005).

\section{d. Interactivity}

Mobile learning promotes interactivity as it allows learners to interact with each other without worrying of the distance through several different applications. Communication among learners is important as it is a form of education (Nordin, Embi, \& Yunus, 2010).

\section{e. Accessibility}

The concept of accessibility can be used by teachers to enhance pedagogical activities in their lessons (Bidin \& Ziden, 2013). Accessibility also let learners to revisit and reflect on acquired knowledge to form a new kind of knowledge (Nordin et al., 2010). Not only that, learners are able to direct their process of learning as they can access and create information by themselves (Yedla, 2013). Besides that, accessibility enables learners to get information almost immediately to answer specific questions.

\section{f. Privacy}

Many individuals have their own mobile devices thus there is no need to share. The learners are able to access their data by themselves without feeling ashamed of their current level of learning. Additionally, learners will interact more with their device due to sense of privacy (Bidin \& Ziden, 2013). This is supported by Zhang (2003) who said that the privacy of these devices will make learners feel safe and motivated.

Additionally, based on the definition and feature, MALL can be beneficial to learners when incorporated into writing activities. Although there might be some challenges in terms of size, durability and sustainability, the educator can make use of mobile devices by using the right pedagogy. This is true as mobile devices should be seen as an extension and not replacing the the existing teaching and learning tools (Bidin \& Ziden, 2013).

\section{The Use of WhatsApp in Language Learning}

The use of WhatsApp in language learning should be aimed to encourage students in learning the lesson especially English. By doing this, the learning process will be student-centered. However, the teacher plays a great role, so the teacher must choose the suitable topic to use in 
the discussion, and should help the student understand the lesson by using various features on WhatsApp application.

Riyanto (2013) argued that WhatsApp allows its users to use their Internet connection to send messages to each other. WhatsApp is like a chat program for mobile phones. Smart phones are becoming increasingly popular and WhatsApp is available for almost all Smart phones. WhatsApp involves not only sending text message but also message broadcasting, files, videos, audio media messages as well as their location using integrated mapping features (Riyanto, 2013).

Riyanto (2013) claimed that users take advantage of WhatsApp to text their friends in other countries without paying the exorbitant international texting costs that come with traditional communications. Rolfe (2013) argued that a big reason for the popularity of such apps is that they allow their users to message one another without paying high fees for text messages.

According to Rambe \& Chipunza (2013) as cited in Awada (2016) WhatsApp could provide the learners with an opportunity to express themselves freely in a non-limited environment thus eliminating the low involvement characterizing the class lectures. Learners could develop technical skills by partaking and utilizing such technology. Studies show that students learn best when they are happy. One thing that keeps all the students happy and occupied most of their free time is their mobile phones. Therefore they were permitted to use them during the class for learning purposes only, in that, they could look up the dictionary on their phones since it was easier and quicker than opening the paper dictionaries.

Recently, students are accustomed in using social media such as WhatsApp, Facebook, Instagram, SMS, and others, but most of them use their first language. Various problems they faced with English such as, in framing grammatically correct sentences; finding the right expressions quickly; inadequate vocabulary, and the fear of committing errors.

Hence, it was essential to identify ways of motivating them to communicate in English through writing. With the help of a questionnaire it is assumed that WhatsApp contributes in motivating language learners to write and read in English since it is the most popular application students used to chat with one another..

\section{Flipped Classroom}

The Flipped Classroom is an instructive model in which the standard address and homework components of a course are "turned around" or "flipped". Flipped classroom regularly includes under studies seeing pre-recorded address recordings preceding going to class and utilizing the class time to take part in under study focused learning exercises like request and critical thinking however it might go up against a wide range of structures.

The idea of the flipped classroom is a mix of switched inside and outside classroom exercises. Understudies assume the liability of the outside-classroom exercises through watching recordings, going by course-related sites, listening to sounds, perusing related references and so forth. Then again, instructors need to make an intuitive inside-classroom environment which upgrades combine work, amass work, hands-on exercises and abnormal state thinking exercises. Ogden, Pyzdrowski and Shambaugh (as cited in Alsowat, 2016) expressed that the flipped classroom way to deal with instructing is "an educational outline that replaces what regularly happens amid an eye to eye address (uninvolved exchange of learning) with drawing in exercises and doles out the address as homework for understudies to finish self-governing outside of class". 
Furthermore, Yuen, Keengwe, Onchwari, and Oigara (2014) stated the flipped classroom is an instructional approach that instructors use to transform the conventional classroom address demonstrate into a more dynamic learning classroom. Flipped learning is an individualized learning. In the flipped classroom, instructors are actualizing separated guideline, issue/extend based learning, request based review, so flipped learning is in a general sense learner-driven (Bergmann \& Sams, 2012). The flipped approach developed in 2006 and is portrayed by the utilization of Screen throwing to convey guideline that can be gotten to whenever and put (Dickenson, 2014). The flipped classroom is not an equivalent word for online recordings; it is the association and the significant learning exercises that happen amid the up close and personal time. It is a domain where understudies assume liability for their own learning and are occupied with their learning and get a customized instruction (Cross \& Board, 2014).

\section{Design of the Study}

\section{METHODOLOGY OF THE STUDY}

This study is conducted in pre-experimental design with one-group pretest-posttest design. This study uses pre-experimental because it does not have random assignment of subject to group or other strategy to control extraneous variable. That is why in this study the researcher just takes one group or class and uses pretest and posttest to see the result of the treatment. The subject is not randomized and there is no pre treatment.

The designed can be diagramed as follow:

Figure .1 One Group Pre-Posttest Design (Ary, 2010)

$\begin{array}{ccc}\text { Y1 } & \mathbf{X} & \text { Y2 } \\ \text { Pretest } & \text { Treatment } & \text { Posttest } \\ & \text { (Independent variable) } & \text { (Dependent variable) }\end{array}$

Explanation:

Y1 = Pre-test for experimental group

$\mathrm{X}=$ The treatment by using WhatsApp

Y2 = Post-test for experimental group

This study measured the effect using WhatsApp on students' writing achievement. The impact was assessed by providing a specific treatment. The effect was known after knowing the significant differences between the students who were taught before using WhatsApp and those who are taught after using WhatsApp. And this design uses quantitative approach because involved complex experiment with many variables and treatments.

\section{Population and Sample}

The Second Grade students of junior high school registered in academic year 2017/2018 at MTsN 1 Konawe are the target of population in this study. The total of population is 240 students.

The samples of the research are the second grade students of Class VIII-2 which consist of 40 students. This class consists of 12 male students and 28 female students. In choosing the sample, the researcher used purposive sampling because of the availability of supporting media owned by students for language learning. Random sampling was also taken since the study design used one group pretest -posttest design. However, because of the unavailability of 
mobile media and online discussions, 10 students were excluded from the samples. Therefore, the final numbers of samples were 30 students.

\section{Procedure of Data Collection}

In this research, the researcher set up a WhatsApp group account named "Espresso English Class". This group will be organized by the researcher. To access and to be a member of this WhatsApp closed groups, the user had to have a WhatsApp account. WhatsApp group will be used by students as a tool or media in writing "my weekly journal". The features in WhatsApp will be used is: Chatting.

Before they join this group, the researcher distributed pre-test of Writing to students to write Personal Recount text that has topic namely "When I was a child".

After pre-test, the class were taught by using a flipped classroom method via WhatsApp group chat. The following lists are brief explanation of the activities that will be done by the teacher and students through WhatsApp group chat.

After the treatments were done, the students were given post-test. They were given a topic about their Ramadhan Fasting Month Experience.

Finally, the students were asked to fill in the motivation questionnaires based on their experience in the flipped classroom by using WhatsApp Messenger as the learning tool. In addition, six of them were interviewed to see the in-depth findings about their experience with WhatsApp in a flipped classroom English learning.

\section{Technique of Data Analysis}

In analyzing the data, the researcher gave the brief summary as follows:

1. Data tabulation and categorization to present a syistematic data organization of students' writing scores in both pretest and posttest based on marking scheme.

2. The students' writing score of pre and post test will be analyzed by paired sample t-test to compare students' Writing achievement before and after treatment.

3. The computation of the paired sample t-test is carried out by using statistical software of SPSS 24.0.

\section{Hypothesis of the Study}

Based on research question, literature review and, theoretical framework. So, the researcher gave the research hypothesis as follows:

- Null Hypotheses $\left(\mathrm{H}_{0}\right)$ : There is no significant effect of WhatsApp utilization on students' writing achievement or significance value $>0.05$

- Alternative Hypotheses $\left(\mathrm{H}_{1}\right)$ : There is significant effect of WhatsApp utilization on students' writing achievement or significance value $<0.05$

\section{Descriptive Analysis}

\section{FINDINGS AND DISCUSSION}

This study employed one group. The descriptive analysis illustrates the results of the tests. It describes the test scores of the students in the experimental group who were taught by using WhatsApp. The pre-test and post-test were given to this group. The pre-test was given before the treatment and the post-test was given after the treatment.

The descriptive analysis was applied to provide the calculation of the mean, the standard deviation of the two variables, the highest scores and the lowest score. The ideal mean and the 
ideal standard deviation are used to determine the scores classification. In categorizing the writing scores, the researcher used the classification in the table of score categories suggested by Jacob et al (1981).

\section{Pre-test}

The pre-test was given before treatments. It was given to the experimental class (VIII-2) as the sample. It aimed to measure the writing composition achievement before the class was given the treatment. The students in experimental group were asked to write a recount text about When I was a child.

Table 1 Descriptive Analysis of the students' Writing Pre-test

\begin{tabular}{|c|c|c|c|}
\hline No & Students' Scores & $\begin{array}{l}\text { Frequency } \\
(\mathrm{N})\end{array}$ & $\begin{array}{c}\text { Percent } \\
(\%)\end{array}$ \\
\hline 1 & 34 & 2 & 7 \\
\hline 2 & 35 & 1 & 3 \\
\hline 3 & 36 & 3 & 10 \\
\hline 4 & 37 & 2 & 7 \\
\hline 5 & 38 & 1 & 3 \\
\hline 6 & 40 & 2 & 7 \\
\hline 7 & 41 & 1 & 3 \\
\hline 8 & 42 & 2 & 7 \\
\hline 9 & 43 & 1 & 3 \\
\hline 10 & 44 & 3 & 10 \\
\hline 11 & 45 & 2 & 7 \\
\hline 12 & 46 & 1 & 3 \\
\hline 13 & 47 & 1 & 3 \\
\hline 14 & 48 & 1 & 3 \\
\hline 15 & 50 & 1 & 3 \\
\hline 16 & 51 & 1 & 3 \\
\hline 17 & 52 & 1 & 3 \\
\hline 18 & 53 & 1 & 3 \\
\hline 19 & 60 & 1 & 3 \\
\hline 20 & 65 & 1 & 3 \\
\hline 21 & 70 & 1 & 3 \\
\hline \multicolumn{2}{|r|}{ Total } & 30 & 100 \\
\hline \multicolumn{2}{|c|}{ Mean } & & 44.5 \\
\hline \multicolumn{2}{|c|}{ Std. Deviation } & & 8.87 \\
\hline \multicolumn{2}{|c|}{ Minimum } & & 34 \\
\hline \multicolumn{2}{|c|}{ Maximum } & & 70 \\
\hline
\end{tabular}

The descriptive analysis of the pretest such as the mean, standard deviation, minimum and maximum score is shown in Table 1. The mean score of the experimental class in the pretest was 44.5 with the standard deviation was 8.87, the maximum score for the pretest of the experimental group was 70 and the minimum score was 34 . The result of the descriptive statistics can be seen in Appendix.

Meanwhile, the result of the scores category on the students' writing achievement of the pretest score of experimental group can be seen in Table 2. 
Table 2 The Score Category of students' Pre-test score

\begin{tabular}{|c|l|c|c|}
\hline $\begin{array}{c}\text { Score } \\
\text { Interval }\end{array}$ & \multicolumn{1}{|c|}{ Category } & Frequency & Percentage (\%) \\
\hline $100-88$ & $\begin{array}{l}\text { Excellent to } \\
\text { very good }\end{array}$ & 0 & 0 \\
\hline $87-75$ & Good to average & 0 & 0 \\
\hline $74-64$ & Fair & 2 & 7 \\
\hline $63-49$ & Poor & 5 & 15 \\
\hline $48-34$ & Very poor & 23 & 80 \\
\hline Total & $\Sigma$ & 30 & 100 \\
\hline
\end{tabular}

Table 2 shows that there were 23 students (80\%) categorized into the very poor category, 5 students $(15 \%)$ categorized into the poor category, $2(7 \%)$ students categorized into the fair category, no students categorized into the good to average category and no students categorized into the excellent to very good category. The excellent to very good category and good to average category were categorized into the high categories. Furthermore, the fair, poor, and very poor category were categorized into the low categories. Therefore, based on the data above, it is concluded that the majority of the students is in very poor category and it means that all students are in low category $(100 \%)$.

\section{Five Aspects of Writing Composition in Pre-test}

The five aspects of writing composition in pre-test on experimental group can be seen in the following table:

Table 3 Five Aspects of Writing Composition in students' Pre-Test

\begin{tabular}{llccccc}
\hline No & \multicolumn{1}{c}{ Aspects } & $\mathrm{N}$ & $\mathrm{Min}$ & Max & Mean & $\begin{array}{c}\text { Std. } \\
\text { Deviation }\end{array}$ \\
\hline 1 & Content & 30 & 13 & 22 & 15.13 & 2.50 \\
2 & Organization & 30 & 7 & 14 & 9.63 & 2.09 \\
3 & Vocabulary & 30 & 7 & 14 & 9.20 & 2.04 \\
4 & LanguageUse & 30 & 5 & 18 & 8.23 & 3.22 \\
5 & Mechanics & 30 & 2 & 4 & 2.30 & 0.53 \\
\hline
\end{tabular}

Table 3 shown the five aspects of writing composition in pre-test of experimental class. There were four parts which were compared above. They were mean score, standard deviation, maximum score and also minimum score.

Firstly, the mean score in pre-test for the content aspect was 15.13. Then, the mean score of organization aspect was 9.63. Next, the vocabulary aspect mean score was 9.20. Then, the mean score of language use aspect was 8.23. The last aspect was mechanic. Its mean score was 2.30. In order to give clearer explanation about these five aspects of mean scores, the following graph can be seen as an illustration for the mean score of five aspects in writing composition.

Figure 2 mean score of five aspects in writing composition

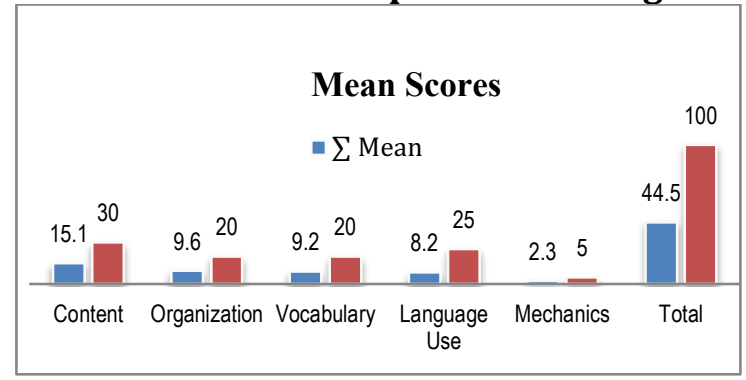


The second part was standard deviation. The standard deviation in pre-test of content aspect was 2.50. Then, the standard deviation of organization aspect was 2.09 . Next , the standard deviation of vocabulary aspect was 2.04. After that, the standard deviation of language use aspect. The standard deviation of language use aspect was 3.22. The last aspect was mechanic. The standard deviation of mechanic aspect was 0.53 . To make the explanation above clear, the following graph can be seen as an illustration for the standard deviation of five aspects in writing composition.

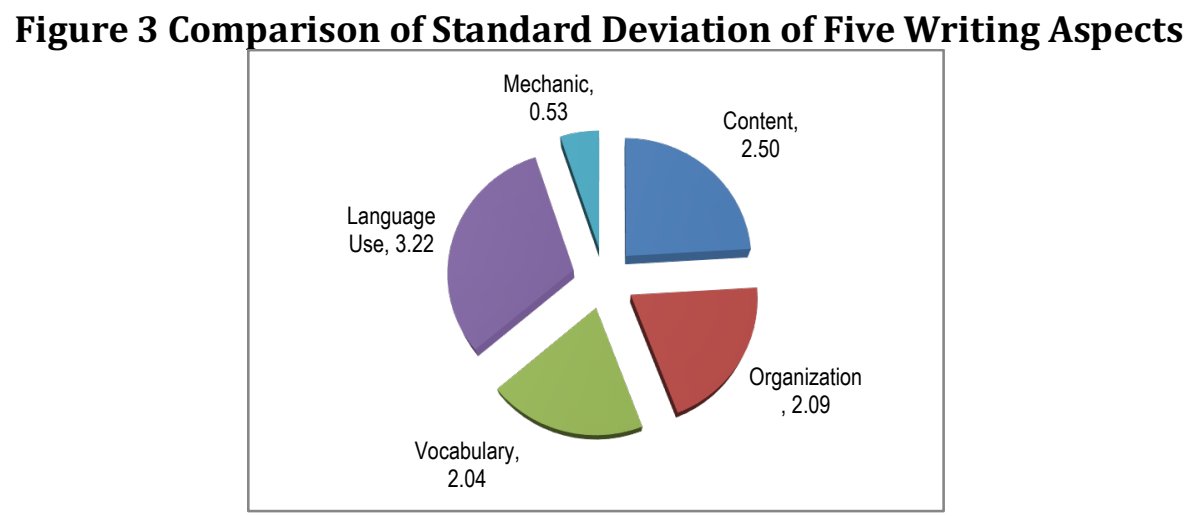

The next part was maximum score. The maximum score in pre-test of content aspect was 22 . Then, the maximum score of organization aspect was 14 . Next was vocabulary aspect. The maximum score of vocabulary aspect was 14 .

Afterwards, the maximum score of language use aspect was 18. The last aspect was mechanic. The maximum score of mechanic aspect was 4 . To make the explanation above clear, the following graph can be seen as an illustration for the comparison of maximum score of five aspects in writing composition.

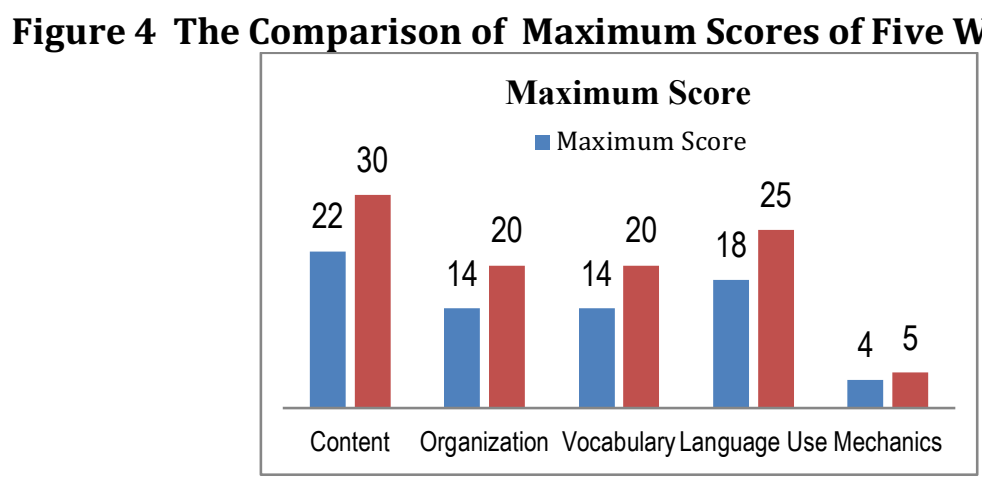

Furthermore, the next part was minimum score the minimum score in pre-test for content aspect was 13. Then, the minimum score of organization aspect was 7. Next was vocabulary aspect. The minimum score of vocabulary aspect was 7 . Then, the minimum score of language use aspect was also 5. The last aspect was mechanic. The minimum score of mechanic aspect was 2 . To make the explanation above clear, the following graph can be seen as an illustration for the comparison of minimum score of five aspects in writing composition.

\section{Post-Test Writing Scores}

The researcher used the software of SPSS version 21 for windows computer program to analyze the quantitative data. From the computation, it shows that the mean score for experimental group in the post-test was 70.36 with the standard deviation was 6.07, the maximum score for the post-test of the experimental group was 84 and the minimum score 61 . 


\begin{tabular}{|c|c|c|c|c|}
\hline No & $\begin{array}{l}\text { Students' } \\
\text { Scores }\end{array}$ & $\begin{array}{l}\text { Frequency } \\
\text { (N) }\end{array}$ & $\begin{array}{c}\text { Percent } \\
(\%)\end{array}$ & $\begin{array}{l}\text { Cumulative } \\
\text { Percent (\%) }\end{array}$ \\
\hline 1 & 50 & 1 & 3 & 3 \\
\hline 2 & 51 & 2 & 7 & 10 \\
\hline 3 & 52 & 1 & 3 & 13 \\
\hline 4 & 54 & 2 & 7 & 20 \\
\hline 5 & 55 & 1 & 3 & 23 \\
\hline 6 & 56 & 2 & 7 & 30 \\
\hline 7 & 57 & 3 & 10 & 40 \\
\hline 8 & 58 & 1 & 3 & 43 \\
\hline 9 & 59 & 2 & 7 & 50 \\
\hline 10 & 60 & 1 & 3 & 53 \\
\hline 11 & 61 & 1 & 3 & 57 \\
\hline 12 & 62 & 1 & 3 & 60 \\
\hline 13 & 63 & 1 & 3 & 63 \\
\hline 14 & 64 & 1 & 3 & 67 \\
\hline 15 & 65 & 1 & 3 & 70 \\
\hline 16 & 66 & 1 & 3 & 73 \\
\hline 17 & 67 & 2 & 7 & 80 \\
\hline 18 & 68 & 1 & 3 & 83 \\
\hline 19 & 71 & 1 & 3 & 87 \\
\hline 20 & 73 & 1 & 3 & 90 \\
\hline 21 & 76 & 1 & 3 & 93 \\
\hline 22 & 84 & 1 & 3 & 97 \\
\hline 23 & 87 & 1 & 3 & 100 \\
\hline Total & & 30 & 100 & 100 \\
\hline \multicolumn{2}{|c|}{ Mean } & & \multicolumn{2}{|l|}{62} \\
\hline \multicolumn{2}{|c|}{ Std. Deviation } & & \multicolumn{2}{|l|}{9.233} \\
\hline \multicolumn{2}{|c|}{ Minimum } & & \multicolumn{2}{|l|}{50} \\
\hline \multicolumn{2}{|c|}{ Maximum } & & \multicolumn{2}{|l|}{87} \\
\hline
\end{tabular}

Meanwhile, the result of the scores categorization on the students' writing achievement of the post-test score of the experimental group can be seen in the Table 5.

Table 5 The Score Category of the Post-test

\begin{tabular}{clcc}
\hline $\begin{array}{c}\text { Score } \\
\text { Interval }\end{array}$ & Category & Frequency & Percentage (\%) \\
\hline $100-88$ & $\begin{array}{l}\text { Excellent } \\
\text { To Very } \\
\text { Good }\end{array}$ & - & - \\
$87-75$ & $\begin{array}{l}\text { Good To } \\
\text { Average }\end{array}$ & 3 & 10 \\
$74-64$ & Fair & 8 & 27 \\
$63-49$ & Poor & 19 & 63 \\
$48-34$ & Very Poor & - & 10 \\
Total & $\sum$ & 30 & $100 \%$ \\
\hline
\end{tabular}

Table 5 shows that there are 19 students (63\%) categorized into the poor category, 8 students $(27 \%)$ into the fair category, 3 students (25\%) were categorized into the good to average category, and there was no students $(0 \%)$ categorized into excellent to very good and very poor category. The excellent to very good category and good to average category were categorized into the high categories. Furthermore, the fair, poor, and very poor category were categorized into the low categories. Therefore based on the data above, it is concluded that the majority of the students are in the fair category and it means that most of the students are in the low category (90\%). 


\section{Five Aspects of Writing Composition in Post-test}

The five aspects of writing composition in post-test on experimental group can be seen in the following table:

\section{Table 6 Five Aspects of Writing Post-Test}

\begin{tabular}{llcccc}
\hline \multirow{2}{*}{ No } & Components & $\begin{array}{c}\text { Mean } \\
\text { Score }\end{array}$ & $\begin{array}{c}\text { Standard } \\
\text { Deviation }\end{array}$ & $\begin{array}{c}\text { Max. } \\
\text { Score }\end{array}$ & $\begin{array}{c}\text { Min. } \\
\text { Score }\end{array}$ \\
\hline 1. & Content & 17.53 & 2.968 & 26 & 15 \\
2. & Organization & 14.97 & 1.205 & 19 & 12 \\
3. & Vocabulary & 10.47 & 2.177 & 15 & 8 \\
4. & Language Use & 14.83 & 2.925 & 24 & 11 \\
5. & Mechanic & 4.20 & 0.484 & 5 & 3 \\
\hline
\end{tabular}

Table 6 shown the five aspects of writing composition in post-test on experimental group. There were four parts which were compared above. They were mean score, standard deviation, maximum score and also minimum score.

Firstly, the mean score in post-test of content aspect was 17.5. Then, the mean score of organization aspect was 15. Next was vocabulary aspect. The mean score of vocabulary aspect was 10.5. In addition, the mean score of language use aspect. The mean score of language use aspect was 14.8. The last aspect was mechanic. The mean score of mechanic aspect was 4.2. To make the explanation above clear, the following graph can be seen as an illustration for the comparison of mean score of five aspects in writing composition.

The next was standard deviation in post-test. For the standard deviation of content aspect was 2.97. Then, the standard deviation of organization aspect was 2.20. Next was vocabulary aspect. The standard deviation of vocabulary aspect was 2.18. Then, the standard deviation of language use aspect was 2.93. The last aspect was mechanic. The standard deviation of mechanic aspect was 0.48 . To make the explanation above clear, the following graph can be seen as an illustration for the comparison of standard deviation of five aspects in writing composition in post-test.

Furthermore, the maximum score of post-test between five aspect in writing. The first was the maximum score of content aspect was also 26. Then, the maximum score of organization aspect was also 19 Next was vocabulary aspect. The maximum score of vocabulary aspect was 15 . The next aspect was language use. The maximum score of language use aspect was 24 . The last aspect was mechanic. The maximum score of mechanic aspect was 5 . To make the explanation above clear, the following graph can be seen as an illustration for the comparison of maximum score of five aspects in writing composition in post-test.

The last part was minimum score in post-test between five aspects of writing composition. For the minimum score of content aspect was 15 . Then, the minimum score of organization aspect was 12 . While the minimum score of vocabulary aspect in post-test was about 8 . Next, the minimum score of language use aspect was 11 . The last aspect was mechanic. The minimum score of mechanic aspect was 3. To make the explanation above clear, the following graph can be seen as an illustration for the comparison of minimum score of five aspects in writing composition in post-test.

\section{Inferential Analysis}

The normality test is employed before testing the hypothesis. The normality test is aimed to see whether the distribution of the students' score is normal or not. In this case, the researcher 
used the Kolmogorov-Smirnov test. Theoretically, the data are normal if the value of $p$ is greater than 0.05 ( $p>0.05)$, it indicates that the data are normally distributed. If it is less or equal than $0.05(\mathrm{p}=0.05)$, the data significantly diverge from a normal distribution. The following table shows the result of normality test of students' pre-test and post-test both in experimental and control class.

\section{Table 7 Result of the Normality Test of Writing Achievement}

\begin{tabular}{|c|c|c|c|}
\hline \multicolumn{4}{|c|}{ One-Sample Kolmogorov-Smirnov Test } \\
\hline $\mathrm{N}$ & & $\begin{array}{c}\text { Pre } \\
\text { Experimental } \\
30\end{array}$ & $\begin{array}{c}\text { Post } \\
\text { Experimental } \\
30\end{array}$ \\
\hline Normal Parameters ${ }^{a}$ & $\begin{array}{l}\text { Mean } \\
\text { Std. } \\
\text { Deviation }\end{array}$ & $\begin{array}{l}62.00 \\
9.233\end{array}$ & $\begin{array}{l}44.50 \\
8.874\end{array}$ \\
\hline Most Extreme & Absolute & .127 & .144 \\
\hline Differences & $\begin{array}{l}\text { Positive } \\
\text { Negative }\end{array}$ & $\begin{array}{l}.127 \\
-.097\end{array}$ & $\begin{array}{l}.144 \\
-.118\end{array}$ \\
\hline $\begin{array}{l}\text { Test Statistic } \\
\text { Asymp. Sig. (2-tailed) }\end{array}$ & & $\begin{array}{l}.127 \\
.200\end{array}$ & $\begin{array}{l}.144 \\
.113\end{array}$ \\
\hline
\end{tabular}

Table 7 shows the result of the normality of pre-test and post-test of experimental groups. The result of normality of the pre-test of experimental group was $0.200\left(P_{\text {Value }}>0.05\right)$ which is higher than 0.05 and the result of normality for post-test of experimental group is $0.113\left(P_{\text {Value }}\right.$ $>0.05$ ) which is also higher than 0.05 . Since all these value are greater than 0.05 , it can be conclude that all of the data have a normal distribution. So, the data are acceptable to be analyzed through parametric statistic test in the form of paired sample t-test on students' pre and post-test score on SPSS 24 to know whether there is a significant effect of using WhatsApp on students' writing achievement or not.

\section{The Analysis of Paired Sample T-Test}

Based on the result of the normality distribution of pre and post-test scores, the computation using paired sample t-test could be done to find out whether there is a significant effect on students' achievement after given treatment using WhatsApp or not.

Table 8 Statistics of Paired Sample t-test of Pre-Test and Post-Test Paired Samples Statistics

\begin{tabular}{lcccc}
\hline & Mean & $\mathbf{N}$ & $\begin{array}{c}\text { Std. } \\
\text { Deviation }\end{array}$ & $\begin{array}{c}\text { Std. Error } \\
\text { Mean }\end{array}$ \\
Pre_Test & 44.50 & 30 & 8.874 & 1.620 \\
Post_Test & 62.00 & 30 & 9.233 & 1.686 \\
\hline
\end{tabular}

The mean score of students' writing achievement in experimental group increased 17.5 points. The mean score of pre-test in experimental group was 44.50 then increased after being taught by using WhatsApp to be 62.00 .

Table 9. Paired Sample t-test of Pre-Test and Post-Test

Paired Differences

$\begin{array}{lccc} & \text { Mean } & \text { T } & \text { Sig. (2-tailed) } \\ \text { Pre_Test - } & -17.5 & -48.451 & .000 \\ \text { Post_Test } & & & \end{array}$


A statistical analysis of paired sample t-test was conducted to find out the effect of WhatsApp on students' writing achievement. The result shows there was a major difference in the mean score $(M=-17.5$, minus indicates the number increased from pre-test to post-test) between pre-test and post-test, with the $\mathrm{t}$-value $=-48.451$, with the hypothesis assumed sig. 0.000 was lower than 0.05 , for the this experimental group. It can be inferred that $\mathrm{H}_{1}$, accepted, that means there is a significant effect of WhatsApp on students' writing achievement at MTsN 1 Konawe according to the study conducted on Class VIII-2. It can be assumed that using WhatsApp gave a significant effect on students' writing achievement at Class VIII-2 of MTsN 1 Konawe

\section{DISCUSSION}

Based on the descriptive analysis, the result of the post-test showed that the mean scores of the post-test were higher than the pre-test. It means that there is an improvement of the mean score on the students' writing achievement. The result of inferential analysis also shows that the data have a normal distribution. Based on the hypothesis testing using a statistical analysis of paired sample t-test, it can be seen that the students who were given WhatsApp in their class had better writing achievement than the students who were not. It is proved from their mean score after being taught by using WhatsApp was higher than their writing mean score before being taught by using WhatsApp. Since the $\mathrm{H}_{0}$ was rejected and $\mathrm{H}_{1}$ was accepted, it can be interpreted that there is significant effect on students' writing achievement. In short, using WhatsApp gave a greater achivement for students' English writing expecially for Class VIII-2 at MTsN 1 Konawe.

The students can improve their writing achievement because the students have more space to maximize their time at home. In WhatsApp messenger, teacher and students could discuss their difficulties in learning English that they met in the classroom. Most of them became more enthusiastic and active. The students became more free to generate and share their ideas, something that could not be achieved when they composed a text without using any media. This finding shows that the use of digital technologies such computer and social network like WhatsApp can shape students' writing in myriad ways including generating ideas, composing, revising, editing, formatting, and printing anything from a single word to a lengthy essay (Purcell et al. 2013; Langan, 2005).

When conducting online session using WhatsApp, teachers can give the students quite time to understand the material, and then giving response. In giving response, students have a longer time to compose a good sentence so that their response will not lead to a misunderstanding. In this circumstance, using online social media like WhatsApp leads students improve their critical reading as well as their writing skill (Alsaleem, 2013; Bouhnik \& Deshen, 2014; Plana et al., 2013; Rambe \& Bere, 2013). Also, the students can gain the knowledge from what their teachers or other students post in WhatsApp, and they can share their knowledge to WhatsApp such as good articles, links, etc. Therefore, other students and teacher can benefit it as well (Awada, 2016).

One of advantages of using WhatsApp is that it can facilitate students in submitting their works, sharing knowledge, knowing their progress, trying to be actively participate in teaching and learning process, interacting with each other without face-to-face meeting, etc.

Lastly, it was confirmed that using WhatsApp in writing would lead to better result than teaching in the classroom or face to face. As the conclusion, the result of this research also proved that WhatsApp was effective to increase students' writing achivement in descriptive 
text. The effect of WhatsApp was also could be seen from the result of this research in experimental group which increased in post-test.

The previous discussions support the social development theory constructed by Vygotsky (1980). The findings of this study support that Constructivist-mobile learning environment imposes new roles for the teacher. Unlike traditional "top-down" teaching, Vygotsky (1980) advocates a bottom-up teaching approach where the teacher facilitates, as opposed to directs, what and how students learn concepts both in and out of the classroom. In the learning setting with the use of mobiles, the teacher should contribute a major role in establishing the learning environment for her/his students. Teacher' role is as facilitator, coacher and co-learner. Her/his responsibility is to help and guide learners throughout their knowledge acquisition. Such a role of providing guidance for learners is, according to Vygotsky, to motivate learners to excel beyond their current skills level (i.e. activating learners' zone of proximal development.); learners are viewed as knowledge constructors. Therefore, Whatsapp is seen as a tool to enhance students' motivation, participation and collaboration in order to make them knowledge constructors.

The main function of WhatsApp platform was providing participants with an open and flexible room for communicating, expressing ideas and exchanging information. However, operating expense involved in WhatsApp use, extra work load, distraction to learning, lack of students' commitment for effective participation, lack of WhatsApp integration skills and small screens of mobile technology were identified as the greatest challenges of effective WhatsApp integration as a learning tool for for small numbers of students. But in the future the challenges will be overcome as the WhatsApp for PC has been available for bigger screen as well as the other new technology arises.

\section{CONCLUSION}

The findings revealed that after using WhatsApp in treatment, the students' score in post-test was better than their score in pre-test. Therefore, after doing statistical test, it was indicated that WhatsApp is an effective learning tool. It was proved from the result of paired sample ttest which shown that the asymp sigm. is 0.000 . It meant that the asymp sig. was lower than $0.05(0.000<0.05)$. So, the $\mathrm{H}_{1}$ is unrejected. It could be concluded that using WhatsApp has significantly affects the students' writing achievement at eighth graders of MTsN 1 Konawe.

\section{References}

Al Hamdani, D. S. (2013). Mobile learning: A good practice. Procedia-Social and Behavioral Sciences, 103, 665-674.

Alsaleem, B. I. A. (2013). The Effect of" WhatsApp" Electronic Dialogue Journaling on Improving Writing Vocabulary Word Choice and Voice of EFL Undergraduate Saudi Students. Arab World English Journal, 4(3).

Alsowat, H. (2016). An EFL Flipped Classroom Teaching Model: Effects on English Language Higher-Order Thinking Skills, Student Engagement and Satisfaction. Journal of Education and practice, 7(9), 108-121.

Awada, G. (2016). Effect of WhatsApp on critique writing proficiency and perceptions toward learning. Cogent Education, 3(1), 1264173.

Beatty, K. (2013). Teaching \& researching: Computer-assisted language learning: Routledge.

Bergmann, J., \& Sams, A. (2012). Flip your classroom: Reach every student in every class every day: International Society for Technology in Education.

Bidin, S., \& Ziden, A. A. (2013). Adoption and application of mobile learning in the education industry. ProcediaSocial and Behavioral Sciences, 90, 720-729.

Bouhnik, D., \& Deshen, M. (2014). WhatsApp goes to school: Mobile instant messaging between teachers and students. Journal of Information Technology Education: Research, 13(1), 217-231.

Cross, A., \& Board, J. (2014). Creative Ways To Teach Primary Science: McGraw-Hill Education (UK). 
Dickenson, P. (2014). „Flipping the Classroom in a Teacher Education Course “. Hrsg. von Jared Keengwe, Grace Onchwari und James N. Oigara, 1, 145-162.

Hubbard, P. (2009). Computer assisted language learning: Critical concepts in linguistics: Routledge.

Jarvis, H. (2015). From PPP and CALL/MALL to a Praxis of Task-Based Teaching and Mobile Assisted Language Use. Tesl-Ej, 19(1), n1.

Nordin, N., Embi, M. A., \& Yunus, M. M. (2010). Mobile learning framework for lifelong learning. Procedia-Social and Behavioral Sciences, 7, 130-138.

Patten, B., Sánchez, I. A., \& Tangney, B. (2006). Designing collaborative, constructionist and contextual applications for handheld devices. Computers \& Education, 46(3), 294-308.

Plana, M. G.-C., Escofet, M. I. G., Figueras, I. T., Gimeno, A., Appel, C., \& Hopkins, J. (2013). Improving learners' reading skills through instant short messages: A sample study using WhatsApp.

Rambe, P., \& Bere, A. (2013). Using mobile instant messaging to leverage learner participation and transform pedagogy at a S outh A frican U niversity of T echnology. British Journal of Educational Technology, 44(4), 544-561.

Riyanto, A. (2013). English language learning using WhatsApp application. AkhmadRianto, Love for All, Hatred for None. WordPress, the Splendid Theme.

Sharples, M., Taylor, J., \& Vavoula, G. (2005). Towards a theory of mobile learning. Paper presented at the Proceedings of mLearn.

Switzer, S., \& Csapo, N. (2005). Survey of student usage of digital technology: Teaching implications. Issues in Information Systems, VI, 1, 127-133.

Valarmathi, K. (2011). Mobile assisted language learning. Journal of Technology for ELT, 2(2), 1-8.

Viberg, O., \& Grönlund, Å. (2012). Mobile assisted language learning: A literature review. Paper presented at the 11th World Conference on Mobile and Contextual Learning.

Vygotsky, L. S. (1980). Mind in society: The development of higher psychological processes: Harvard university press.

Warschauer, M., \& Healey, D. (1998). Computers and language learning: An overview. Language teaching, 31(2), 57-71.

Yedla, S. (2013). MALL (mobile assisted language learning): A paradise for English language learners. Journal of English Language \& Translation Studies, 1(2), 91-99.

Yuen, C. L., Keengwe, J., Onchwari, G., \& Oigara, J. (2014). Using the flipped classroom instructional approach to foster a mathematics-anxious-friendly learning environment. Promoting active learning through the flipped classroom model, 245-268.

Zhang, D. (2003). Delivery of personalized and adaptive content to mobile devices: a framework and enabling technology. Communications of the Association for Information Systems, 12(1), 13. 